\title{
Role of MicroRNAs in the Epithelial-to-Mesenchymal Transition in Oral Squamous Cell Carcinoma: A Systematic Review
}

\author{
Salomão IML Queiroz ${ }^{1, *}$, Mara LB Severo², Rafaella B Leite ${ }^{3, *}$, Laura PB de Carvalho², Roseana de A Freitas², Leão P Pinto², and \\ Lélia B de Souza²
}

${ }^{1}$ Departamento de Odontologia, Universidade Federal do Rio Grande do Norte, Natal, RN, Brazil

2Programa de Pós-Graduação em Patologia Oral, Universidade Federal do Rio Grande do Norte, Natal, RN, Brazil

${ }^{3}$ Avenida Senador Salgado Filho, Universidade Federal do Rio Grande do Norte, Programa de Pós-graduação em Patologia Oral, Brazil

*Corresponding authors: Salomão IML Queiroz, Departamento de Odontologia, Universidade Federal do Rio Grande do Norte (UFRN), Natal, RN, Brazil, Tel: (084) 3215-4138; E-mail: salomaoisrael10@gmail.com

Rafaella B Leite, Avenida Senador Salgado Filho, Universidade Federal do Rio Grande do Norte, Programa de Pós-graduação em Patologia Oral 1787-Lagoa Nova, Brazil, Tel: (084) 3215-4138; E-mail: rrafaella_bastos@hotmail.com

Received: 02 Oct, 2019 | Accepted: 23 Oct, 2019 | Published: 29 Oct, 2019

Citation: Queiroz SIML, Severo MLB, Leite RB, de Carvalho LPB, de A Freitas R, et al. (2019) Role of MicroRNAs in the Epithelial-toMesenchymal Transition in Oral Squamous Cell Carcinoma: A Systematic Review. Int J Dent Oral Health 5(6): dx.doi.org/10.16966/23787090.307

Copyright: (C) 2019 Queiroz SIML, et al. This is an open-access article distributed under the terms of the Creative Commons Attribution License, which permits unrestricted use, distribution, and reproduction in any medium, provided the original author and source are credited.

\begin{abstract}
Purpose: MicroRNAs have been recognized as regulators of many biological and pathological processes, and represent candidate molecules for the treatment of diverse cancers. However, their role in Epithelial-to-mesenchymal Transition (EMT), although well studied, has generated many questions, especially in Oral Squamous Cell Carcinoma (OSCC). This review aims to clarify the role of microRNAs during EMT in OSCC.
\end{abstract}

Methods: A systematic review was conducted using PubMed, Web of Science, Scientific Electronic Library Online, Scopus, Cochrane Library, Science Direct, and BVS (Biblioteca Virtual emSaúde).

Results: A total of 2411 articles were analyzed, out of which 14 were selected based on the inclusion and exclusion criteria. Various microRNAs were reported in these studies, and the miR-200 family was evaluated in most studies; it has been established that this family of micro RNA induces direct inhibition of molecules in the TGF- $\beta$ pathway.

Conclusion: Given the critical role of microRNAs in EMT, and the subsequent development of metastatic tumors, the inhibition of EMT through microRNAs can offer an important therapeutic strategy for targeting tumor metastasis in OSCC.

Keywords: Squamous cell carcinoma; Epithelial-mesenchymal transition; MicroRNAs; MiRNAs review

\section{Introduction}

Squamous cell carcinoma of the head and neck, like other epithelial cancers, occurs due to the accumulation of genetic and epigenetic alterations [1]. As the tumor progresses, it acquires the ability to invade the surrounding tissues and metastasize, which contributes to poor prognosis. In early metastasis, neoplastic cells demonstrate reduced ability to adhere to each other and exhibit increased mobility by undergoing Epithelial-mesenchymal Transition (EMT), a process through which the cells undergo transformation from an epithelial to a mesenchymal phenotype [1,2].

During the acquisition of mesenchymal features, neoplastic cells lose the expression of genes that promote cell-cell contact, such as E-cadherin, and gain the expression of mesenchymal markers, such as vimentin, fibronectin, and $\mathrm{N}$-cadherin, which promote cell migration and invasion [3]. Although efforts have been made to identify the molecular mechanisms that contribute to the onset and progression of cancer, most of the focus has been on the protein-coding genes that control tumor progression. Our studies have produced new findings that highlight the important role of microRNAs $[1,2,4]$.

MicroRNAs (miRNAs) are highly conserved 18-25 nucleotide long, small non-coding RNAs, which act as regulators of gene expression through translational repression or degradation of messenger RNA (mRNA) [1]. Depending on the target gene, approximately half of the human miRNAs can function as tumor suppressors or oncogenes [5].

Recently, microRNAs have been recognized as key regulators of many pathological processes, including tumor formation, progression, metastasis, and self-renewal, and differentiation of stem cells $[2,6,7]$. In addition, the difference between expression profiles of microRNAs in normal tissue and in various types of malignant neoplasms has confirmed their close relationship with tumorigenesis; Additionally, several microRNAs have been shown to directly regulate the transcription factors involved in EMT [1,7-9]. 
Owing to their ability to regulate various target genes involved in tumor progression and metastasis, microRNAs have emerged as potential therapeutic candidates in cancer. Thus, we performed a literature review of microRNAs involved in the regulation of EMT, to identify the potential targets for the treatment of Oral Squamous Cell Carcinoma (OSCC).

\section{Materials and Methods}

In this systematic review, we searched the following databases: PubMed, Web of Science, Scientific Electronic Library Online (SciELO), Scopus, the Cochrane Library, Science Direct, and the BVS (Biblioteca Virtual emSaúde) research portal. Manuscripts published in English, Spanish, or Portuguese within the last 10 years were included in this review. We employed several different search strategies within each database through word and keyword searches using the DeCS- Health Sciences Descriptors (Table 1). Owing to the retrospective nature of this study, a written exemption was obtained from the Institutional Review Board of University Federal of Rio Grande do Norte, Natal, Rio Grande do Norte, Brazil.

The initial step of selecting and qualifying the publications addressing the role of microRNA during EMT in OSCC, involved the analysis of the title and summary. Two reviewers further refined the selection based on the study design. In case of disagreement between the two reviewers, a third reviewer was involved in the process and served as a tie breaker. The third reviewer was blinded to the decisions of the other two reviewers, as seen in table 2 (Selection and qualification of papers). Studies where analysis of microRNAs during the EMT process was not the main objective were excluded.

\section{Results}

Sixty articles were selected based on the chosen keywords and reviewed; of these, 21 were met the inclusion criteria of this study. After a second round of review, seven more articles were excluded

Table 1: Databases searched and search strategy used for each.

\begin{tabular}{|l|l|}
\hline Database & \multicolumn{1}{|c|}{ Search Strategy } \\
\hline $\begin{array}{l}\text { PubMed, Web } \\
\text { of Science and } \\
\text { ScienceDirect }\end{array}$ & $\begin{array}{l}\text { (microRNA or miRNA) and (epithelial-mesenchymal } \\
\text { transition or EMT or Cell migration) and (squamous } \\
\text { cell carcinoma or oral cancer or oral squamous cell } \\
\text { carcinoma or OSCC) }\end{array}$ \\
\hline $\begin{array}{l}\text { SciELO and } \\
\text { Cochrane Library }\end{array}$ & (microRNA or miRNA) \\
\hline Scopus & $\begin{array}{l}\text { (microRNA OR miRNA) and (epithelial-mesenchymal } \\
\text { transition) and (squamous cell carcinoma) }\end{array}$ \\
\hline BVS & (microRNA OR miRNA) and (oral cancer) \\
\hline
\end{tabular}

as they discussed microRNAs in carcinomas located outside the oral cavity. The data from the 14 articles selected for this systematic review are described in detail in table 3.

Diverse families of microRNAs were reported in the selected articles. Most of the articles had evaluated the role of the miR-200 family, and it was found that the functions of this family were driven by NUAK1, ZEB1, ZEB2, and GRHL2-mediated signaling in EMT. Several other target genes, such as Twist Family bHLH Transcription Factor 1 (Twist1), Snail Family Transcriptional Repressor 1 (Snail), Snail Family Transcriptional Repressor 2 (Slug), SRY-box Transcription Factor 4 (Sox4), SRY-box Transcription Factor 9 (Sox9), Inhibit Subunit beta A (INHBA), Transforming Growth Factor Beta Receptor 2 (TGFBR2), and A Disintegrin and Metalloprotease Domain 17 (ADAM17), have also been reported as EMT modulators that are directly influenced by microRNAs. Another important aspect addressed was the modulation of chemoresistance by microRNAs (Let-7, miR-181a, and miR-134). Patient survival was also addressed in relation to microRNA expression (miR-153, miR-200c, miR-143, miR-145, miR-204, and miR-155). Generally, the down regulation of microRNAs was associated with poor patient survival.

In almost all the articles analyzed, the silencing or down regulation of microRNAs induced EMT; the exception being miR-155-5p, whose high expression was associated with poor patient survival and EMT.

\section{Discussion}

\section{Expression of miRNA and development of OSCC}

EMT is a prerequisite for cancer metastasis. During this process, the neoplastic cells of the primary tumor acquire a mesenchymal phenotype, lose polarity and cell-cell adhesion, dissociate from the neighboring cells, thereby acquiring the ability to metastasize through vascular invasion [3]. As EMT is closely related to tumor metastasis, resistance to treatment, and poor prognosis, many studies have investigated the possible causes of EMT [1,10-12].

MicroRNAs are post-transcriptional regulators of genes involved in various biological processes, including proliferation, differentiation, development, senescence, and apoptosis. Recent studies have highlighted their important role in various aspects of tumor formation, such as tumor initiation, growth, differentiation, EMT, and progression $[1,3,13]$.

\section{Invasion and metastasis of OSCC and the role of miRNA}

Let-7 was one of the first mammalian microRNAs identified [14]. Studies on several types of human cancers, including lung, gastric, ovary, and colon, have revealed that the let-7 family is expressed at low levels during cancer progression [14,15]. Chang CJ, et al. [4]

Table 2: Selection and qualification of papers.

\begin{tabular}{|c|c|c|c|c|}
\hline Database & Original number of papers & Papers selected based on title & Papers selected based on abstract & Papers involving OSCC \\
\hline PubMed & 352 & 96 & 30 & 21 \\
\hline Web of Science & 413 & 89 & 26 & 15 \\
\hline SciELO & 441 & 5 & 2 & 1 \\
\hline Scopus & 118 & 40 & 20 & 14 \\
\hline Cochrane Library & 333 & 8 & 1 & 0 \\
\hline Science Direct & 447 & 69 & 22 & 8 \\
\hline BVS & 307 & 22 & 6 & 1 \\
\hline Total & 2411 & 329 & 107 & $60^{\mathrm{a}}$ \\
\hline
\end{tabular}

aSeveral articles were repeated between the results of the searches; however, a total of 21 unique articles were left. 
Table 3: Selected articles used in this study with a description of the miRNAs studied in the context of EMT.

\begin{tabular}{|c|c|c|c|c|c|c|c|}
\hline Authors & miRNA & Cell line & Known function & Correlations & Action & Target & Function \\
\hline $\begin{array}{l}\text { Chang CJ, } \\
\text { et al. } 2011 \\
\text { [4] }\end{array}$ & Let-7d & OECM1 & $\begin{array}{l}\text { Regulates } \\
\text { senescence of } \\
\text { blood cells }\end{array}$ & $\begin{array}{l}\text { Conversely proportional to } \\
\text { EMT factors TWIST1 and } \\
\text { SNAIL }\end{array}$ & $\begin{array}{l}\text { Tumor } \\
\text { suppressor }\end{array}$ & RAS/HGMA2 & $\begin{array}{l}\text { EMT regulation } \\
\text { and modulation of } \\
\text { chemoresistance }\end{array}$ \\
\hline $\begin{array}{l}\text { Xu Q, et al. } \\
2013[21]\end{array}$ & $\begin{array}{l}\text { miR-153 and } \\
\text { miR-200c }\end{array}$ & $\begin{array}{l}\mathrm{HN}-4 \text { and } \\
\mathrm{HN}-12\end{array}$ & - & $\begin{array}{l}\text { Directly proportional to the } \\
\text { epithelial phenotype Inversely } \\
\text { proportional to SNAI1 and } \\
\text { ZEB2 }\end{array}$ & $\begin{array}{l}\text { EMT } \\
\text { suppressor }\end{array}$ & $\begin{array}{l}\text { 153: SNAI1 e } \\
\text { ZEB2 } \\
\text { 200c: ZEB1 e } \\
\text { ZEB2 }\end{array}$ & $\begin{array}{l}\text { Low expression } \\
\text { correlates with } \\
\text { low survival and } \\
\text { increased metastasis }\end{array}$ \\
\hline $\begin{array}{l}\text { Liu M, et al. } \\
2013[16]\end{array}$ & miR-181a & $\begin{array}{l}\text { Cal27 and } \\
\text { SCC15 }\end{array}$ & $\begin{array}{l}\text { Regulation of } \\
\text { chemoresistance } \\
\text { in leukemia }\end{array}$ & $\begin{array}{l}\text { ETM directly related to } \\
\text { chemoresistance }\end{array}$ & $\begin{array}{l}\text { EMT } \\
\text { suppressor }\end{array}$ & TWIST1 & $\begin{array}{l}\text { Reversal of } \\
\text { chemoresistance and } \\
\text { EMT regulation }\end{array}$ \\
\hline $\begin{array}{l}\text { Harazono Y, } \\
\text { et al. } 2013 \\
{[8]}\end{array}$ & miR-665 & Tumor tissue & - & - & $\begin{array}{l}\text { EMT } \\
\text { suppressor }\end{array}$ & $\begin{array}{l}\text { ZEB1 and } \\
\text { TGFBR2 }\end{array}$ & $\begin{array}{l}\text { EMT regulation and } \\
\text { prognostic marker }\end{array}$ \\
\hline $\begin{array}{l}\text { Yu CC, et al. } \\
2013 \text { [29] }\end{array}$ & miR-145 & HNCS & - & - & $\begin{array}{l}\text { Tumor } \\
\text { suppressor }\end{array}$ & $\begin{array}{l}\text { SOX9 and } \\
\text { ADAM17 }\end{array}$ & $\begin{array}{l}\text { Low expression with } \\
\text { low Survival, EMT } \\
\text { regulation }\end{array}$ \\
\hline $\begin{array}{l}\text { Yu J, et al. } \\
2014 \text { [20] }\end{array}$ & miRNA-300 & HNSCC & - & $\begin{array}{l}\text { Inversely proportional to } \\
\text { TWIST1 and metastasis }\end{array}$ & $\begin{array}{l}\text { EMT } \\
\text { suppressor }\end{array}$ & TWIST1 & $\begin{array}{l}\text { and metastasis } \\
\text { regulation }\end{array}$ \\
\hline $\begin{array}{l}\text { Lin Z, et al. } \\
2014 \text { [15] }\end{array}$ & miR-639 & $\begin{array}{l}\text { SCC9 and } \\
\text { Cal27 }\end{array}$ & - & $\begin{array}{l}\text { Inversely proportional to } \\
\text { lymph node metastasis }\end{array}$ & $\begin{array}{l}\text { Tumor } \\
\text { suppressor }\end{array}$ & FOXC1 & $\begin{array}{l}\text { Low expression with } \\
\text { lower survival and } \\
\text { metastasis }\end{array}$ \\
\hline $\begin{array}{l}\text { Zheng M, } \\
\text { et al. } 2015 \\
{[25]}\end{array}$ & miR-101 & $\begin{array}{l}\text { Cal 27, Tca } \\
8113, \text { SCC-9 } \\
\text { and SCC-4 }\end{array}$ & - & $\begin{array}{l}\text { Over expression of Snail } \\
\text { and Slug correlated with } \\
\text { metastasis, poor prognosis, } \\
\text { lower expression of miR-101 } \\
\text { and higher expression of } \\
\text { EZH2 }\end{array}$ & $\begin{array}{l}\text { EMT } \\
\text { suppressor }\end{array}$ & $\mathrm{EZH} 2$ & $\begin{array}{l}\text { EMT and metastasis } \\
\text { regulation }\end{array}$ \\
\hline $\begin{array}{l}\text { Bufalino A, } \\
\text { et al. } 2015 \\
\text { [2] }\end{array}$ & $\begin{array}{l}\operatorname{miR}-143 \text { e } \\
\operatorname{miR}-145\end{array}$ & $\begin{array}{l}\text { SCC-4,-9,-15 } \\
\text { and SCC-25 }\end{array}$ & - & $\begin{array}{l}\text { High levels of Activin A } \\
\text { suppresses apoptosis }\end{array}$ & $\begin{array}{l}\text { Tumor } \\
\text { suppressor }\end{array}$ & $\begin{array}{l}\text { ACTIVIN A } \\
\text { (INHBA) }\end{array}$ & $\begin{array}{l}\text { EMT and lymph node } \\
\text { metastasis regulation }\end{array}$ \\
\hline $\begin{array}{l}\text { Li T, et al. } \\
2015[14]\end{array}$ & miR-34a & $\begin{array}{l}\text { OC3, } \\
\text { COM-E1, } \\
\text { TCa-8113, } \\
\text { SCC-25 and } \\
\text { DOK }\end{array}$ & - & $\begin{array}{l}\text { miR-34a inhibits proliferation } \\
\text { and induces G1 arrest } \\
\text { miR-34a correlated inversely } \\
\text { with IL6R }\end{array}$ & $\begin{array}{l}\text { Tumor } \\
\text { suppressor }\end{array}$ & IL6R & $\begin{array}{l}\text { Malignant behavior, } \\
\text { including cell } \\
\text { proliferation and } \\
\text { invasion }\end{array}$ \\
\hline $\begin{array}{l}\text { Jensen DH, } \\
\text { et al. } 2015 \\
\text { [9] }\end{array}$ & $\begin{array}{l}\text { miR-200c and } \\
\text { miR-141 }\end{array}$ & Tumor tissue & - & $\begin{array}{l}\text { Decreased expression of } \\
\text { miR-200c and miR-141 on the } \\
\text { invasive front }\end{array}$ & $\begin{array}{l}\text { EMT } \\
\text { suppressor }\end{array}$ & $\begin{array}{l}\text { ZEB1 and } \\
\text { PRRX1 }\end{array}$ & EMT regulation \\
\hline $\begin{array}{l}\text { Obayashi } \\
\text { M, et al. } \\
2016[18]\end{array}$ & miR-203 & SpSCC & $\begin{array}{l}\text { Suppression } \\
\text { of cellular } \\
\text { metabolic activity }\end{array}$ & $\begin{array}{l}\text { miR-203 suppresses invasion } \\
\text { NUAK1 is involved in invasion } \\
\text { and EMT }\end{array}$ & $\begin{array}{l}\text { Tumor } \\
\text { suppressor }\end{array}$ & NUAK1 & EMT regulation \\
\hline $\begin{array}{l}\text { Yu CC, et al. } \\
2016[28]\end{array}$ & miR-204 & $\begin{array}{l}\text { S-G } \\
\text { SAS }\end{array}$ & - & $\begin{array}{l}\text { miR-204/low Slug/high Sox4/ } \\
\text { high }\end{array}$ & $\begin{array}{l}\text { EMT } \\
\text { suppressor }\end{array}$ & $\begin{array}{l}\text { SOX4 and } \\
\text { SLUG }\end{array}$ & $\begin{array}{l}\text { Low expression with } \\
\text { lower survival and } \\
\text { increased metastasis }\end{array}$ \\
\hline $\begin{array}{l}\text { Baba O, et } \\
\text { al. } 2016 \text { [1] }\end{array}$ & miR-155-5p & $\begin{array}{l}\text { HaCaT and } \\
\text { HSC-3 }\end{array}$ & - & $\begin{array}{l}\text { High expression of miR-155- } \\
5 p \text { was associated with poor } \\
\text { overall survival }\end{array}$ & EMT stimulator & $\begin{array}{l}\text { STAT3 } \\
\text { (SOCS1) }\end{array}$ & EMT regulation \\
\hline
\end{tabular}

corroborated these findings by demonstrating that the expression of let-7d in metastasized OSCC was significantly decreased compared to that in the primary tumor, whereas the expression of Twist and Snail (key components of EMT) was increased. In support of this correlation, a change from the epithelial to mesenchymal phenotype was also observed after treatment withalet-7d-SPONGE.

In 2013, Liu M, et al. [16] elucidated the role of microRNAs and Twist in EMT, thereby establishing Twist as a target of miR-181a, which influenced E-cadherin and Vimentin levels, and consequently cell phenotype. Additionally, silencing of the Twist attenuated the chemoresistance and metastatic potential of the tumor. These results were supported by those of Shin KH, et al. [17-19] which showed that miR-181a was often down regulated in OSCC and its ectopic expression suppressed proliferation and increased anchorage, independent of the growth capacity of OSCC.

Other factors such as the Transforming Growth Factor-beta (TGF- $\beta$ ) pathway induce EMT by directly changing gene expression. TGF- $\beta$ family proteins that act through the Smad transcription factors, 
wants acting through beta-catenin and TCF/LEF transcription factors, and Hedgehog proteins that activate Glioma-Associated Oncogene (Gli) proteins, all induce or are required for EMT in diverse contexts $[9,18,19]$.

TGF- $\beta$ receives substantial attention, largely because of its ability to induce EMT in cell culture and its crucial role in cancer-associated EMT. Further, TGF- $\beta$ family proteins are known to direct EMT during development. TGF- $\beta$ acts by activating key signaling pathways involved in EMT such as the MAP Kinase (MAPK) and PI3-AktmTOR pathways $[9,18,19]$.

Twist is a component of the TGF- $\beta$ pathway, which represses E-cadherin, and a major target of microRNAs. In 2014, Yu J, et al. [20] sought to clarify this regulatory pathway based on the knowledge that miR-300 was down regulated in cancer cells undergoing EMT relative to that in cells with epithelial phenotypes. Ectopic expression of miR300 effectively blocked the EMT-mediated induction of the TGF- $\beta$ pathway through the reversal of the mesenchymal phenotype in $\mathrm{HN}$ 12 and MDA-MB-231 cells. Twist was revealed as a direct target of miR-300. Clinically, the reduction in miR-300 levels is associated with metastatic events.

Determining the role of microRNAs in EMT and subsequent metastasis remains the objective of several OSCC studies. Micro RNA families such as the miR-200 family, which were found in the altered gene pool, are powerful negative regulators of EMT $[9,19]$. Xu Q, et al. [21] concluded that a decrease in miR-200c expression was required for EMT, with its targets ZEB1 and ZEB2 favoring the transition from an epithelial to a mesenchymal phenotype. Similarly, Harazono Y, et al. [8] identified ZEB1 and TGFBR2 as direct targets of miR-655 and Jensen DH, et al. [9] identified ZEB1 and Paired Related Homeobox 1 (PRRX1) as possible miR-200c targets [21]. In addition, the expression of several other components of the TGF- $\beta$ signaling pathway (SNAIL, SLUG, and TWIST1) can be reduced directly or indirectly through the over expression of miR-655 in cancer cells-treated with or without TGF- $\beta$ which demonstrated that microRNAs can significantly alter the expression of several components of the signaling cascade [22].

In another study investigating the effect of TGF- $\beta$ signaling on EMT, Lin Z, et al. [15] evaluated the regulatory role of miR-639 in SCC9 and CAL27 cells. They observed a down regulation of miR-639 in TGF- $\beta$ treated SCC 9 cells, and found that its ectopic expression in both cell types inhibited EMT. This regulation also occurred through the Fork head Box C1 (FOXC1), a TGF- $\beta$ target gene, which plays an important role in several cellular processes, such as proliferation, apoptosis, and differentiation. Clinically, it was observed that a reduction in miR639 expression was associated with metastasis and poor survival. Therefore, the high expression of FOXC1 decreased the expression of epithelial markers and increased the expression of mesenchymal markers $[23,24]$.

$\mathrm{Xu} \mathrm{Q}$, et al. [21] also examined miR-153, and showed that SNAI1 (of Snail family) and ZEB2-which are recognized as transcriptional repressors of E-cadherin-to be its direct targets. E-cadherin is a central component of the adherence junction complex that is responsible for cell-cell adhesion, and the loss of which is an important event in EMT. Similarly, Zheng M, et al. [25] showed that Enhancer of Zeste Homolog 2 (EZH2) was also a potential target of miR-101. They found that a decrease in miR-101 expression-mediated by Slug and Snailactivated EZH2 which induced EMT, cell migration, and invasion by bringing about epigenetic gene silencing through histone methylation. The over expression of Slug and Snail was also shown to be correlated with metastasis and poor prognosis. Real-time PCR analysis the background of the silencing of these genes demonstrated that 22 miRNAs were up regulated. Especially, the expression of EZH2 at the transcriptional as well as translational levels was reduced in CAL27 cells in the background of miR-101 over expression. Thus, the EMT process would be accelerated by loss of miRNA-101.

Other positive regulators of cancer signaling pathways are SOX9 [26] and SOX4 [27]. Yu CC, et al. [28] confirmed that miR-145low/ SOX9high/ADAM17may indicate lower patient survival and proposed that the SOX9/ADAM17 axis might serve as a target through which miR-145 could regulate tumor initiation. Bufalino A, et al. [2] who suggested that activin A is a possible target for miR-145 demonstrated that both miR-143 and miR-145 are markedly down regulated in OSCC cell lines and tissue specimens. This was inversely correlated with the expression of activin A, implying that miR-143 and miR-145 expression in cells significantly decreased the expression of activin A. This homodimeric protein encoded by the INHBA gene is a multifunctional member of the TGF- $\beta$ family and plays important roles in cell growth, differentiation, and apoptosis in events related to angiogenesis, inflammation, immunity, and embryogenesis. As a result, defects in INHBA expression have been associated with uncontrolled cell proliferation and survival, which lead to the development and progression of cancer [24].

\section{The role of miRNA in the diagnosis and treatment of OSCC}

Baba O, et al. [1] demonstrated that miR-155-5p was significantly up regulated in OSCC cell lines and in cervical lymph node metastases from 73 patients with OSCC. HSC-3 cells exhibited an increase in E-cadherin expression and a decrease in $\mathrm{N}$-cadherin and vimentin expression when transfected with a miR-155-5p inhibitor. Moreover, the up regulation of Suppressor of Cytokine Signaling 1 (SOCS1) and the down regulation of Signal Transducer and Activator of Transcription 3 (STAT3) were observed in HSC-3 cells transfected with the miR-155-5p inhibitor. Thus, miR-155-5p expression was significantly correlated with cervical lymph node metastasis and poor prognosis in OSCC.

Owing to the critical role of EMT in the formation of metastatic tumors, the inhibition of EMT appears to be an important therapeutic strategy for the prevention of tumor metastasis. Given the prognostic progress and predictive value for tumor development, a detailed molecular analysis of EMT is the first step towards the elucidation of targets for developing drugs that may inhibit this process. At present, the TGF- $\beta$ pathway appears particularly promising, but other targets, such as Interleukin 6 Receptor (IL6R), NUAK1, and SOX9, have also been studied $[1,5]$.

IL6R is a subunit of the interleukin 6 (IL-6) receptor complexes, which is a potent regulator of cell growth and differentiation, and plays an important role in the immune response. IL-6/6R signaling is closely associated with tumor growth and poor prognosis [20] Du J, et al. [5] found that miR-34a expression was lower in oral cancer tissues than that in normal tissues. They also showed that the over expression of miR-34a in oral cancer cells could inhibit cell proliferation, G1 phase retention, metastasis, and EMT, thereby inhibiting the progression of oral cancer by regulating IL6R expression.

NUAK1 is a member of the AMP-activated Protein Kinases (AMPKs), which are highly conserved molecules that function as metabolic sensors. Their activity has been linked to the regulation of metabolism and the maintenance of polarity under conditions of stress [25]. Obayashi M, et al. [18] suggested that NUAK1 might be involved in mediating the invasion and induction of EMT in HNSCC as it is targeted by miR-203. Interestingly, over expression and knockout of 
NUAK1 did not alter the cell morphology or expression of related molecules such as E-cadherin, $\mathrm{N}$-cadherin, vimentin, and members of the Snail family (SNAIL1 and SNAIL2).

\section{Conclusion}

Although studies on the role of microRNAs in oral cancer are scarce and are restricted to the evaluation of possible targets, the present systematic review has identified the potential roles of microRNAs in carcinogenesis. However, this review serves as a guide for the development of more appropriate therapeutic modalities that would represent a substantial advancement in the diagnosis and prognosis of oral cancer patients. Finally, this study supports new studies that show that microRNAs play a therapeutic role in cancer.

\section{Conflict of Interest}

Authors declare has no conflict of interest.

\section{Source of Funding}

None declared.

\section{References}

1. Baba O, Hasegawa S, Nagai H, Uchida F, Yamatoji M, et al. (2016) MicroRNA-155-5p is associated with oral squamous cell carcinoma metastasis and poor prognosis. J Oral Pathol Med 45: 248-255.

2. Bufalino A, Cervigne NK, de Oliveira CE, Fonseca FP, Rodrigues PC, et al. (2015) Low miR-143/miR-145 Cluster levels induce activin A overexpression in oral squamous cell carcinomas, which contributes to poor prognosis. PLoS One 10: e0136599.

3. Chen W, Yi JK, Shimane T, Mehrazarin S, Lin YL, et al. (2016) Grainyhead-like 2 regulates epithelial plasticity and stemness in oral cancer cells. Carcinogenesis 37: 500-510.

4. Chang CJ, Hsu CC, Chang CH, Tsai LL, Chang YC, et al. (2011) Let-7d functions as novel regulator of epithelial-mesenchymal transition and chemoresistant property in oral cancer. Oncol Rep 26: 10031010.

5. Du J, Li L, Ou Z, Kong C, Zhang Y, et al. (2012) FOXC1, a target of polycomb, inhibits metastasis of breast cancer cells. Breast Cancer Res Treat 131: 65-73.

6. Ebert MS, Sharp PA (2012) Roles for microRNAs in conferring robustness to biological processes. Cell 149: 515-524.

7. Gregory PA, Bert AG, Paterson EL, Barry SC, Tsykin A, et al. (2008) The miR-200 family and miR-205 regulate epithelial to mesenchymal transition by targeting ZEB1 and SIP1. Nat Cell Biol 10: 593-601.

8. Harazono Y, Muramatsu T, Endo H, Uzawa N, Kawano T, et al. (2013) miR-655 is an EMT-suppressive microRNA targeting ZEB1 and TGFBR2. PLoS One 8: 627-657.

9. Jensen $D H$, Dabelsteen $E$, Specht L, Fiehn AM, Therkildsen $M H$, et al. (2015) Molecular profiling of tumour budding implicates TGF $\beta$ mediated epithelial-mesenchymal transition as a therapeutic target in oral squamous cell carcinoma. J Pathol 236: 505-516.

10. Jiang SS, Fang WT, Hou YH, Huang SF, Yen BL, et al. (2010) Upregulation of SOX9 in lung adenocarcinoma and its involvement in the regulation of cell growth and tumorigenicity. Clin Cancer Res 16: 4363-4373.

11. Jin Y, Chen D, Cabay RJ, Wang A, Crowe DL, et al. (2013) Role of microRNA-138 as a potential tumor suppressor in head and neck squamous cell carcinoma. Int Rev Cell Mol Biol 303: 357-385.

12. Kim NH, Kim HS, Li XY, Lee I, Choi HS, et al. (2011) A p53/miRNA-34 axis regulates Snail1-dependent cancer cell epithelial-mesenchymal transition. J Cell Biol 195: 417-433.
13. Korpal M, Lee ES, Hu G, Kang Y (2008) The miR-200 family inhibits epithelial-mesenchymal transition and cancer cell migration by direct targeting of E-cadherin transcriptional repressors ZEB1 and ZEB2. J Biol Chem 283: 14910-14914.

14. Li T, Li L, Li D, Wang S, Sun J (2015) MiR-34a inhibits oral cancer progression partially by repression of interleukin-6-receptor. Int J Clin Exp Pathol 8: 1364-1373.

15. Lin Z, Sun L, Chen W, Liu B, Wang Y, et al. (2014) MiR-639 regulates transforming growth factor beta-induced epithelial-mesenchymal transition in human tongue cancer cells by targeting FOXC1. Cancer Sci 105: 1288-1298.

16. Liu M, Wang J, Huang H, Hou J, Zhang B, et al. (2013) miR-181aTwist1 pathway in the chemoresistance of tongue squamous cell carcinoma. Biochem Biophys Res Commun 441: 364-370.

17. Mactier KE, Glaire MA, Basavaraju U, El-Omar EM, Hold GL (2014) MicroRNAs in gastrointestinal malignancy: a tool in cancer prevention? Eur J Cancer Prev 23: 540-549.

18. Obayashi $M$, Yoshida $M$, Tsunematsu, Ogawa I, Sasahira $T$, et al. (2016) microRNA-203 suppresses invasion and epithelialmesenchymal transition induction via targeting NUAK1 in head and neck cancer. Oncotarget 7: 8223-8239.

19. Shin KH, Bae SD, Hong HS, Kim RH, Kang MK, et al. (2011) MiR181a shows tumor suppressive effect against oral squamous cell carcinoma cells by downregulating K-ras. Biochem Biophys Res Commun 404: 896-902.

20. Yu J, Xie F, Bao X, Chen W, Xu Q (2014) miR-300 inhibits epithelial to mesenchymal transition and metastasis by targeting Twist in human epithelial cancer. Mol Cancer 13: 121.

21. Xu Q, Sun Q, Zhang J, Yu J, Chen W, et al. (2013) Downregulation of miR-153 contributes to epithelial-mesenchymal transition and tumor metastasis in human epithelial cancer. Carcinogenesis 34 : 539-549.

22. Suzuki A, Kusakai G, Kishimoto A, Lu J, Ogura T, et al. (2003) Identification of a novel protein kinase mediating Akt survival signaling to the ATM protein. J Biol Chem 278: 48-53.

23. Takamizawa J, Konishi H, Yanagisawa K, Tomida S, Osada $\mathrm{H}$, et al. (2004) Reduced expression of the let-7 microRNAs in human lung cancers in association with shortened postoperative survival. Cancer Res 64: 3753-3756.

24. Weiss A, Attisano L (2013) The TGFbeta superfamily signaling pathway. Wiley Interdiscip Rev Dev Biol 21: 47-63.

25. Zheng $M$, Jiang YP, Chen $W$, Li KD, Liu X, et al. (2015) Snail and Slug collaborate on EMT and tumor metastasis through miR-101mediated EZH2 axis in oral tongue squamous cell carcinoma. Oncotarget 6: 6794-6810.

26. Yanaihara N, Caplen N, Bowman E, Seike M, Kumamoto K, et al. (2006) Unique microRNA molecular profiles in lung cancer diagnosis and prognosis. Cancer Cell 9: 189-198.

27. Yi H, Cho HJ, Cho SM, Jo K, Park JA, et al. (2012) Blockade of interleukin- 6 receptor suppresses the proliferation of $\mathrm{H} 460$ lung cancer stem cells. Int J Oncol 41: 310-316.

28. Yu CC, Chen PN, Peng CY, Yu CH, Chou MY (2016) Suppression of miR-204 enables oral squamous cell carcinomas to promote cancer stemness, EMT traits, and lymph node metastasis. Oncotarget 15: 20180-20192.

29. Yu CC, Tsai LL, Wang ML, Yu CH, Lo WL, et al. (2013) miR145 Targets the SOX9/ADAM17 Axis to Inhibit Tumor-Initiating Cells and IL-6Mediated Paracrine Effects in Head and Neck Cancer. Cancer Res 73: 3425-3440. 